\title{
Improving the Transitional Care for Child Dental Nursing via the Use of Documentary Films
}

\author{
Yanqiu Tonga, Xianzhou Yang, Yang Songb, Juan Luoc
}

\begin{abstract}
The purpose of this paper is utilizing quasi-experimental study to evaluate the educational value of a documentary film for transitional care about children dental health management. The method used in this study is a pre-post survey among nurse viewers. The study was completed over a 12-month period. In the experimental group, when the nurses watched the documentary film, they evaluated the documentary film highly and reported an intention to change their transitional care practice and mind as a result of watching the documentary film. Following viewing, children and their parents felt more strongly that "children with dental problems should meet with a nurse early" and that "transitional care greatly impacts children oral health". As a result, a documentary film about oral transitional care is an effective educational tool to improve nurses' transitional care awareness among children about the importance and needs of children. The results suggest that if significant modifications are obtained, this approach can be an efficient way applicable to other contexts of patient care.
\end{abstract}

\section{Keywords}

Transitional care, documentary film, dental health management

Pediatric dentistry is a special kind of dental clinic, where the treated children are with age from 0 to 18 years old. Due to the fact that these children have little ability and awareness about oral health management, after treatment they can only rely on the nurses for their oral health care. So it is important for the nurses to provide timely knowledge of children's oral health management. At this point, providing appropriate educational resources for transitional care is an effective way to promote nurses' skills of transitional care.

The audio-visual arts have been used to help physicians and medical students better understand the experience of patients and instill empathy. In the educational research field, the use of audio-visual materials can date back to decades ago, and is based on several models ranging from simple teaching goals to the interactive learning environments and even new media learning platform. Using audio-visual materials for education covers several fields including physics, mathematics, chemistry, sports, health care, and therapeutic counseling.

In order to improve the nursing skills of transitional care for child dental management, the authors consider a documentary film as a digital resource. And the

aChongqing Jiaotong University, Chongqing, China bChongqing Medical University, Chongqing, China cThe Affiliated Hospital of Stomatology of Chongqing Medical University, Chongqing, China

\section{Correspondent Author:}

Xianzhou Yang, Yi Xue Yuan Road, Yu Zhong District, \#1, Chongqing Medical University, Chongqing, China 
authors seek to exploit and design learning activities to broadcast it locally or via the Internet.

From the perspective of delivery information, documentaries as an audio-visual media can transform the different types of knowledge into audio-visual forms. For different areas of education, documentaries are used in a face-to-face mode or online courses [such as open course and MOOCs (Massive Open Online Courses)] to convey content that may be used for several purposes:

(1) Helping to build new knowledge;

(2) Assisting in strengthening knowledge;

(3) Addressing constraints on the acquisition of a type of knowledge.

The explanation of the contents previously mentioned is not sufficient to facilitate the educational use, so it must be supplemented by action of annotation that allows different contents to be enriched by adding more information. Then the authors developed a documentary film detailing the experiences of transitional care of children oral health management to increase learner awareness.

\section{DOCUMENTARY FILM AND KNOWLEDGE-ACQUIRE}

Documentary film can provide a type of learning experience. Learning is a holistic process in which a learner experiences an integrated meaning-making experience from learning materials (Andresen, Boud, and Cohen 2000). Learning is also an inner experience that is socially and culturally influenced and constructed by the learner. Thus, a documentary film can facilitate learners actively to construct their own understanding with continuous reflection upon their learning experience.

Documentary film can help learners to construct meaningful learning. In this context, constructivism could provide a very important basis for exploring a learner's internal experience in convergence education. Constructivism emphasizes that knowledge is actively constructed by a learner and that meaning-making occurs through connections with prior knowledge and the real world (Marshall 1988; von Glasersfeld 1991). Constructing meaningful learning experiences in nursing education requires "active" participation from all the learners. Through such participation, they can make their own learning outcomes. Learners are immersed in a documentary film created audio-visual environment. In this environment, a learner is regarded as a participant who makes her own inner experience through learning and, therefore, is encouraged to cognitively participate in relating (learning in the context of one's working experiences or preexisting knowledge), applying (learning by putting concepts to use), and transferring (using knowledge in a novel situation that has not been covered in class).

The purpose of the present study was to explore the characteristics of learners' internal experience when studying learning material integrated from diverse academic subjects, focusing on cognitive and emotional experiences and their changes during learning (Shin and Cho 2015).

\section{METHODS}

According to cone of experience and Gagne's classification of knowledge, the knowledge of children's oral transitional care is divided into declarative knowledge and procedural knowledge. For this study, an educational documentary, The Story of the Teeth, was selected. A documentary usually includes interconnected phenomena and knowledge from various fields under one common theme, which explains its convergent characteristic (Aitken 2013). The documentary was originally broadcasted on an app called WeChat. WeChat is a cross-platform instant messaging service developed by Tencent in China, which was first released in January 2011. It is one of the largest standalone messaging apps by monthly active users. WeChat provides text 
messaging, hold-to-talk voice messaging, broadcast (one-to-many) messaging, video conferencing, video games, sharing of photographs and videos, and location sharing. As the title suggests, the documentary explores the various methods of transitional care for child dental nursing.

When the authors were considering what documentary was suitable for this study, three factors were considered as selection criteria. First, a documentary should be able to provide varied learning experiences to the viewers (nurses, children, or children's parents). An important consideration was to ensure that viewers were fully aware of any learning experience while watching the video. Second, a documentary should include various independent themes and contents from expert academic fields. Third, it should be certainly aesthetic and artistic.

The authors' research hypothesis is that after the nurses watched the documentary film, the level of their transitional care was higher.

\section{PROCEDURE}

A standard procedure was used to analyze viewers' experience with the documentary film. First, according to the contents, the documentary was split into some meaning sections, or key knowledge units, and then data from the viewers' experience were collected in a unit by unit sequence (Ascher and Pincus 2007; Li, Narayanan, and Kuo 2004). In this study, the entire documentary was divided into 15 units based on key knowledge and events introduced in the documentary. These 10 meaning sections consisted of two meaning components, which were "declarative" and "procedural". Declarative referred to "what to do and to do what", and discourse represented "how to do".

A semi-structured interview method was suitable for collecting the data on the participants' learning experience after watching the documentary (Saka 2010). Semi-structured questions were prepared for the interview, mainly asking about the interviewees' thoughts and feelings on the contents of the documentary film. The benefit of using the semi-structured interviewees is that it can freely allow the interviewee to express their opinions and gain interviewees' tacit knowledge on the main contents.

\section{DATA ANALYSIS}

All interview data were recorded and transcribed. When all the nurses had watched the documentary film, the authors used Likert scales to evaluate how this documentary film changed their attitudes after viewing the film. Likert scale is named after Rensis Likert (1903-1981), it is a summated rating scale because the scale score is a simple sum of responses over items. There are some items that allow respondents to express degrees of agreement, such as "Strongly agree", "Agree", “Agree somewhat", "Disagree somewhat", "Disagree", and "Strongly disagree" rather than a simple choice between agreement and disagreement. All viewers felt that the documentary film was of high-quality audio-visual effect (9.27 on a ten-point Likert scale) and important (9.03), that they learned something useful from the film (8.67), and that the film was an effective way to teach about transitional care for child dental health management (8.98), and should be seen by all parents caring for their children (9.23). And then the authors sent this documentary film to parents of children, their attitudes also changed (see Table 1).

\section{RESULTS}

After viewing the film, viewers were more likely to agree that "transitional care greatly impacts the children's dental health". They were less likely to believe that "transitional care is primarily someone else's job" (see Table 2).

As time went on, the viewers began constructing their own new meaning knowledge from watching the 
Table 1. Attitudes Among Nurses (NS) and Children's Parents (PR)

\begin{tabular}{|c|c|c|c|c|}
\hline Attitudes & Group & $\begin{array}{l}\text { Response mean } 1-10 \text { scale: } \\
(1=\text { strongly disagree; } 10=\text { strongly agree }) \\
N=300\end{array}$ & $\begin{array}{l}\text { ANOVA } \\
\text { F statistic }\end{array}$ & $P$ value \\
\hline $\begin{array}{l}\text { Giving attention to children dental } \\
\text { health management is important }\end{array}$ & $\begin{array}{l}\text { NS } \\
\text { PR }\end{array}$ & $\begin{array}{l}7.64 \\
8.73\end{array}$ & 1.63 & $<.01$ \\
\hline Family care is also important & $\begin{array}{l}\text { NS } \\
\text { PR }\end{array}$ & $\begin{array}{l}4.58 \\
5.67\end{array}$ & 1.56 & $<.01$ \\
\hline $\begin{array}{l}\text { Transitional care greatly impacts } \\
\text { children oral health }\end{array}$ & $\begin{array}{l}\text { NS } \\
\text { PR }\end{array}$ & $\begin{array}{l}9.16 \\
7.68\end{array}$ & 1.32 & $<.01$ \\
\hline $\begin{array}{l}\text { Children with dental problems } \\
\text { should meet with a nurse early }\end{array}$ & $\begin{array}{l}\text { NS } \\
\text { PR }\end{array}$ & $\begin{array}{l}9.82 \\
9.73\end{array}$ & 1.08 & $<.01$ \\
\hline $\begin{array}{l}\text { The film is an effective way to teach } \\
\text { about transitional care }\end{array}$ & $\begin{array}{l}\text { NS } \\
\text { PR }\end{array}$ & $\begin{array}{l}6.82 \\
8.54\end{array}$ & 2.67 & $<.01$ \\
\hline $\begin{array}{l}\text { The film should be seen by all } \\
\text { parents caring for their children }\end{array}$ & $\begin{array}{l}\text { NS } \\
\text { PR }\end{array}$ & $\begin{array}{l}9.78 \\
7.67\end{array}$ & 7.87 & $<.01$ \\
\hline $\begin{array}{l}\text { The film is of high quality } \\
\text { audio-visual effect }\end{array}$ & $\begin{array}{l}\text { NS } \\
\text { PR }\end{array}$ & $\begin{array}{l}4.54 \\
5.47\end{array}$ & 7.76 & $<.01$ \\
\hline
\end{tabular}

documentary film. At the beginning, participants paid more attention to the documentary's production process and tried to understand the main story from the producer's point of view. So the viewers put learning direction externally, because learning was guided by this external material. However, as participants watched the documentary film, they gradually developed their learning direction internally. After they changed their own learning direction, they became more active in using their prior knowledge and experience to reconstruct their own knowledge from the documentary film.

The knowledge of transitional care for child dental nursing was shown by documentary film and the documentary film was made up of some shots. Participants said that knowledge points in the documentary film seemed to be fragmentary at the beginning. However, as learning progressed, participants seemed to find their own epiphanies. And they then made their own tacit knowledge based on those epiphanies. After they made their own knowledge structure, participants actively predicted the meaning of new knowledge based on this structure.
In the study, participants (pre-test group and post-test group) also experienced changes in cognition and emotions (see Figure 1). The most emotional change was when participants realized that they could not only understand the document's main content, but also produce their own meanings as a result of converting their learning experience.

Cognitive change in learning is usually accompanied by change in emotion, and these two areas cannot be considered separately from each other (Zembylas 2005). In the authors' study, emotional change was found when participants were successful in converting their learning experiences. That was rebuilding a new personal knowledge structure.

\section{CONCLUSIONS}

A documentary film about the knowledge and experience of transitional care of dental health management, viewed by nurses, was well received and reported to be important, relevant, and useful for improving their nursing skills. Viewers thought that the film was an effective way to teach about transitional care and that even all children and their 
Table 2. The Scores During Different Periods

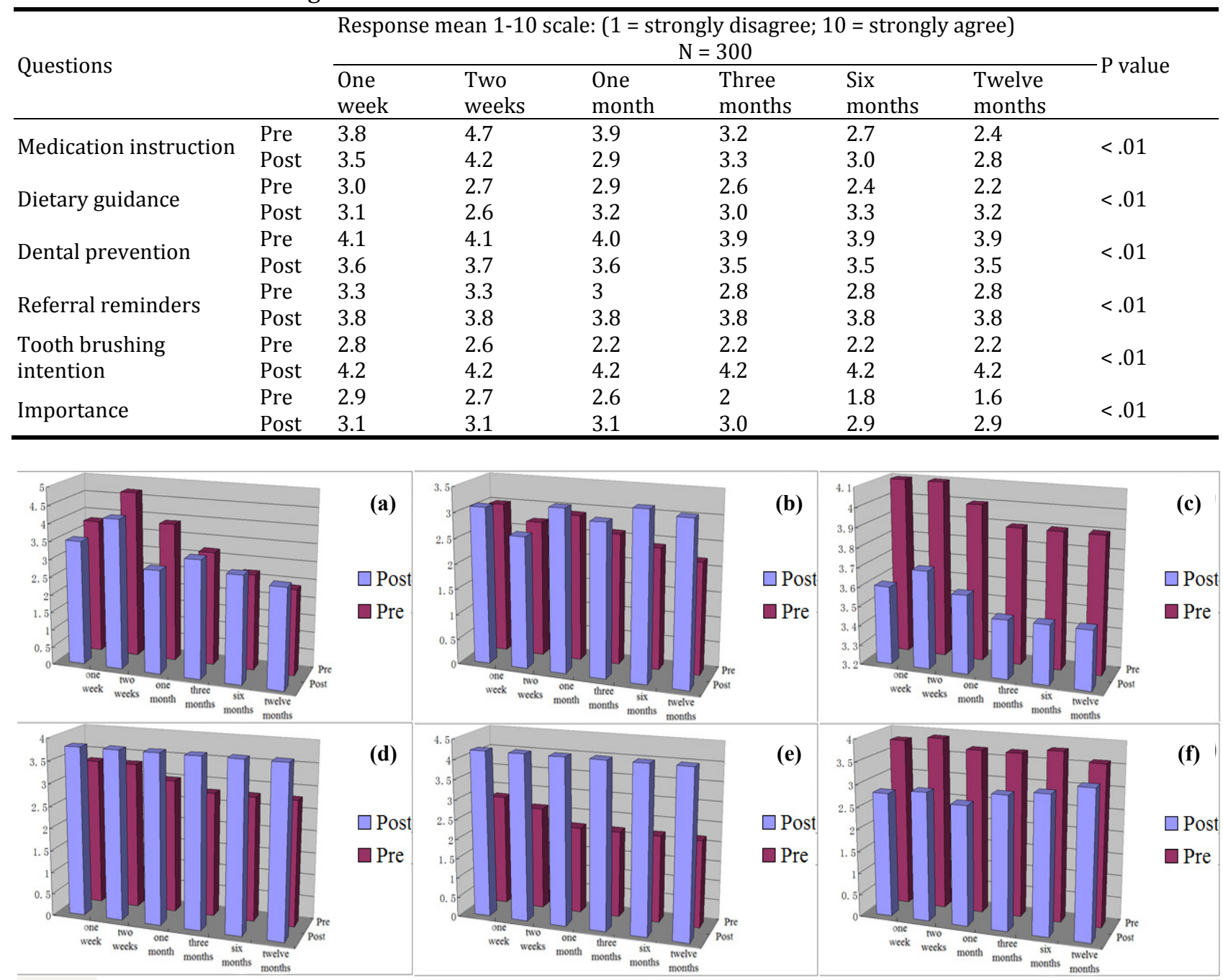

Figure 1. The Results of Pre and Post (a) Medication Instruction; (b) Dietary Guidance; (c) Dental Prevention; (d) Referral Reminders; (e) Self-consciousness; and (f) Importance.

parents should watch the film. In summary, nurses viewed the documentary film that created new meaning learning and their own knowledge structure from learning materials.

\section{Funding}

This work was supported by humanities and social sciences research project of Chongqing social science planning and training project (2014PY46), Chongqing Education Commission (16SKGH022), humanities and social sciences research project of Chongqing Education Commission (16SKGH084).

\section{References}

Aitken, I. 2013. Encyclopedia of the Documentary Film. New York, NY: Routledge.

Andresen, L., D. Boud, and R. Cohen. 2000. "Experience-Based Learning." Pp. 225-239 in Understanding Adult Education and Training, edited by G. Foley. Sydney: Allen \& Unwin.

Ascher, S. and E. Pincus. 2007. The Filmmaker's Handbook: A 
Comprehensive Guide for the Digital Age. New York, NY: Penguin.

Bernstein, I. H. 2005. "Likert Scale Analysis." Encyclopedia of Social Measurement 2:497.

Bransford, J. D., A. L. Brown, and R. R. Cocking. 2000. How People Learn. Washington, D.C.: National Academy Press.

Chatman, S. B. 1990. Coming to Terms: The Rhetoric of Narrative in Fiction and Film. Ithaca, NY: Cornell University Press.

Hariri, A. and H. Fihri-Fassi. 2013. "Using Documentaries for Designing Elearning Activities." Procedia-Social and Behavioral Sciences 116(2014):2752-2753.

Kumagai, A. K. 2008. "A Conceptual Framework for the Use of Illness Narratives in Medical Education." Acad Med 83:653-658.

Li, Y., S. Narayanan, and C. C. Kuo. 2004. "Content-Based Movie Analysis and Indexing Based on Audiovisual Cues." IEEE Transactions on Circuits and Systems for Video Technology 14(8):1073-1085.

Lorenz, K. A., M. J. Steckart, and K. E. Rosenfeld. 2004. "End-of-Life Education Using the Dramatic Arts: The Wit Educational Initiative." Acad Med 79:481-486.

Marshall, H. H. 1988. "Work or Learning Implications of Classroom Metaphors." Educational Researcher 17(9):9-16.

Saka, A. Z. 2010. "Investigation of Student-Centered Teaching Applications of Physics Student Teachers." Eurasian Journal of Physics and Chemistry Education 1(1):51-58.

Self, D. J. and D. C. Baldwin. 1990. "Teaching Medical Humanities Through Film Discussions." J Med Humanit 11:23-29.

Shin, J. and E. Cho. 2015. "Characteristics of Convergence Learning Experience Using an Educational Documentary
Film.” Asia Pacific Education Review 16(2):213-223.

von Glasersfeld, E. 1987. The Construction of Knowledge: Contributions to Conceptual Semantics. Seaside, CA: Intersystems.

- 1991. "Cognition, Construction of Knowledge, and Teaching." Pp. 117-132 in History, Philosophy, and Science Teaching, edited by M. R. Matthews. New York, NY: Teachers College Press.

Weber, C. M. and H. Silk. 2007. "Movies and Mess." Fam Med 39:317-319.

Zembylas, M. 2005. "Three Perspectives on Linking the Cognitive and the Emotional in Science Learning: Conceptual Change, Socio-constructivism and Poststructuralism." Studies in Science Education 41(1):91-115.

\section{Bios}

Yanqiu Tong, Ph.D. candidate, associate professor, Faculty of Humanities, Chongqing Jiaotong University, Chongqing, China; research fields: TV documentary making, new media, bio-sensor.

Xianzhou Yang, M.S., associate research assistant, Chongqing Medical University, Chongqing, China; research fields: medicine education, medicine development.

Yang Song, M.S., associate research assistant, Chongqing Medical University, Chongqing, China; research field: medicine educational technology.

Juan Luo, licensed practical nurse, The Affiliated Hospital of Stomatology of Chongqing Medical University, Chongqing, China; research field: psychological counseling for children with non cooperation. 